\title{
PENGARUH PENDIDIKAN DAN PELATIHAN TERHADAP PRODUKTIVITAS KERJA PEGAWAI KECAMATAN DI KABUPATEN PIDIE
}

\author{
Armiwal \\ (Dosen Prodi Ilmu Sosial Politik Fakultas Sosial Politik Universitas Iskandarmuda Banda Aceh)
}

\begin{abstract}
ABSTRAK
Pendidikan merupakansuatukegiatan atau usaha manusiauntuk meningkatkan kepribadiannya, dengansuatuprosesperubahan prilaku menuju kedewasaan denganpengembangan kemaampuan atauprilakukearah yang diinginkan, sertarnerupakan hasil atau prestasiyang dicapai oleh perkembangan manusia.

Pendidikandanpelatihanrnerupakansalahsatusaranapenting diselenggarakan olehsetiap institusi untuk meningkatkan prestasi kerja sebagai sumber daya manusia dimana dalam penyelenggaraantersebutmenjadi proses belajarmengajardalamrangka mendidik dan melatih para peserta untuk rnenambah pengetahuan, ketrampilan dan perubahan sikap.

Tujuandilaksanakanpendidikandanpelatihanbagipegawai negerisipil sebagaimana disebutkan dalarn pasal 31 Undang-undang Nomor 43 Tnhun 1999 tentang Pokok-pokok Kepegawaian adalah Untuk mencapai daya guna dan hasil guna yang sebesar-besarnya diadakan pengaturan dan penyelenggaraan pendidikan dan latihan pegawai negeri sipil yang bertujuan untuk meningkatkan pegabdian, mutu, keahlian, kemampuan dan ketrampilan.

Untuk kelancarandanperkembanganproduktivitaskerjapegawai diperlukan adanya pengembangankemampuanmelaluiPendidikandanPelatihan dengan adanyapengembangan pengetahuan dan kemampuan kerja maka akan menjadikan pegawai lebih dan kreatif dan juga akan berkontribusi dengan baik dalarn semua pekerjaan yang diberikan.Bahwa masing-masing pegawai negeri sipil pada kantor Camat menduduki jabatan sesuai dengan pangkat, begitu juga halnya penernpatan para pegawai disetiap seksi, dapat disimpulkan sudah memenuhi standart kepangkatan. pengalaman kerja dan pendidikan,berdasarkanUndang-undang Nomor : 43 Tahun 1999 tentang Perubahan atas Undang-undang Nomor 8 Tahun 1974 tentang Pokok-pokok Kepegawaian.

Rendahnya prestasi kerja pegawai kantor Camat di Kabupaten Pidie dalam menjalankan tugas yang dibebankankepadanya tersebut dikarenakan kurangnya mendapatkan pembinaan dari pimpinan sehingga pegawai lalaidalammenjalankan tugas-tugas yang diberikan kepada pegawai yang bersangkutan.
\end{abstract}

Keywords:Pendidikan dan Pelatihan terhadap Produktivitas Pegawai.

\section{PENDAHULUAN}

Pemerintah Indonesia telah menyadari sepenuhnyakeberhasilanPembangunan

Nasional. KegiatanPembangunan Nasionaldari talun ketahun bahwa Sumber Daya Manusia (SDM)yang berkualitas merupakan modal utamasekaligusmerupakankunci

meningkatsearah dengan perkembanganilrnu pengetahuan dan teknologi. Pembangunan yang dilakukan tersebut bertujuan untuk mewujudkan rnasyarakat adil dan makmur yang merata dan berkesinambungan antara materil dan spirituil berdasarkan Pancasila dan Undang-undang Dasar 1945.

Untuk mencapai tujuan tersebut pemerintah terus berusaha menggalakkan dan mendorong perkembangandan kegiatan pembangunan yang serasi dan saling mengisi antara semua sektor yang ada.

Namun dalarn kenyataan, perkembangan pembangunan itu sendiri belum dirasakan sepenuhnya oleh semua lapisan masyarakat terutama yang mendiami daerah-daerah yang sangat jauhdari sentralperekonomian. Padahal daerah tersebut mempunyai potensialam yang cukupbesar, salahsatu penyebabnya adalah kurangnya sumber daya manusiayangakanmembangundan mengembangkandaerahtersebut.Demi tercapainya tujuan pemerintah tersebut periu adanyaperbaikan kualitas, wawasan dan disiplin yang berdaya guna dan berbasil guna pada setiap pegawai. Dan kegiatan pengembangan pegawai ini dapat ditempuh melalui program pendidikan dan pelatihan. Hal ini 
bertujuan juga unruk meningkatkan pengetahuan dan ketrarnpilan pegawai sehingga mampu menyelesaikan dan menganalisis setiappekerjaan maupun tugastugasyangdibebankan kepadanya,Bukti-bukti menunjukkan bahwa program pendidikan dan pelatihan merupakan langkah terbaik untuk rneningkatkan kualitas dan produktivitas pekerja dari segi pengetahuan dan kctrampilan dalam sebuah organisasi.Dan dengan perkembangan zaman di globalisasi seperti ini, maka pengetahuandanketrampilansangatlah utama.

Sejarah telah rnembuktikan bahwa sebagian besar ncgara- negara industri baru diAsia rnencapai tujuan diberbagai sektor bukan disebabkan oleh kekayaanSumber Daya Manusia (SDM) yang handal, Ini bermakna bahwa pernbangunan suatu ncgara dalam berbagai sektor ditentukan oleh kualitas surnber daya rnanusianya. Keberadaan pegawai merupakan perangkai lunak selaku sendi utamauntuk menjalankansegala tugastugas yang ada dalarnrangkamencapai tujuan yang telah ditetapkan didalam dinas tersebut,

Oleh karenaitu kelangsungan keberadaan pegawai tersebutharus ditopang oleh suatu kekayaan sumber daya rnanusia yang sangat berpengalaman dan handal.

Di dalam Undang-undang Nomor 43 Tahun1999 tersebut dijelaskan bahwa dalam usaha mencapaitujuannasionalyaitu mewujudkan rnasyarakat adil dan rnakmur yang merata material dan spiritual diperlukan adanyaPegawai Negeri Sipil scbagai warga, unsur aparatur,abdi negara dan abdi rnasyarakat yang penuh kesetiaan dan ketaatan kepada Pancasila, Undang-undangdasar 1945 negara dan pemerintah serta yang bersatu padu bermental baik. berwibawa, berdaya guna, bersih.bermututinggi, dan sadar akan langgung jawabnya untuk menyelenggarakan tugas pernerintah dan pembangunan.

\section{KERANGKA PEMIKIRAN DAN TINJAUAN KEPUSTAKAAN}

Untukmencapaitujuandari

organisasi/perusahaan diperlukan adanya pengembangan karyawan atau pegawainya. pengembangan ini dapat dilakukan melalui pendidikan dan pelatihan yang di laksanakan secara teratur dan sempurna.

Pendidikan rnenurut Hasibuan (2002:69) adalah segala usaha untuk membiasakan kepribadiandanmengembangkan kemampuan manusia baik dibidang jasmani maupun rohani yang berlangsung seumur hidup,baik didalam maupun diluar sekolah, dalam rangka pernbangunan persatuan dan masyarakat adil dan makmur berdasarkan Pancasila dan Undang-undang.

Secara Konseptual menurut Siswanto (2005:200). Pendidikan adalah segala sesuatu untuk membina kepribadian dan rnengembangkan kemampuan manusia, jasmaniah dan rohaniah yang berlangsung seumur hidup baik didalam manpun diluar sekolah untuk pembangunan persatuan dan rnasyarakat adil dan rnakmur dan selalu ada dalam keseimbangan.

Menurut Dictionary of Education. Pendidikan diartikan sebagai berikut: Proses dimana seseorang rnengembangkan kemampuan, sikap dan bentuktingkah laku lainnya dalam masyarakat dimana dia hidup. Proses sosial dimana orang dihadapkan pada pengaruh lingkunganyang terpilih dan terkontrol,khususnya yang datang darisekolah, sehingga mereka dapai rnemperoleh atau mengalami perkembangan kemampuan sosial dan kemampuan individu yang optimum.

Grow and crow mengartikan Pendidikan adalah suatu proses dimana pengalaman atau informasi diperoleh sebagai hasil dari proses belajar.Pendidikanmencakup pengalaman, pengertian dan penyesuaian diridan pihak terdidik terhadap rangsangan yang diberikan kepadanya menuju kearah pertumbuhan dan perkembangan,

Menurut UU No. 20 Tahun 2003 Pendidikan adalah usaha sadar dan terencana untuk mewujudkan suasana belajar dan proses pembelajaran agar peserta didik secara aktif mengembangkan potensi dirinya untuk rnemiliki kekuatanspritual keagamaan. pengendalian diri. kepribadian, kecerdasan, akhlak mulia.Serta ketrampilan yang diperlukan dirinya, rnasyarakat, bangsa, dan negara.

Pendidikan atau education secara umum rnerupakan usaha yang sengaja diadakan dan dilakukan secara sistematis serta terus menerus dalam jangka waktutertentu sesuai dengan tingkatannyaguna

menyampaikannya,menumbuhkan. dan mendapatkan pengetahuan, sikap, nilai kecakapan atau ketrampilan yang dikehendakinnya. 
Menurut Dessler (2007:45) Pelatihan merupakan "Suatu proses mengajarkankepada karyawan baru atau yang ada sekarang, ketrampilan dasar yangdibutuhkan untuk menjalankan pekerjaan. Pelatihan berfokus pada ketrarnpilan yang dibutuhkan untuk menjalankan pekerjaan karyawan sekarang, pengembangan karyawan dan manajemen yang bersifat jangka panjang. Arahnya adalah mengembangkan karyawan sekarang dan mendatang untuk tugas-tugas masa depan atau memecahkan masalah organisasi.

Menurut Rolf P. Lynton dan Udai pareek, Pelatihan adalah mempersiapkan peserta latihan untuk mengambil jalur tindakan tertentu yang dilukiskan oleh tekhnologi dan organisasi tempat bekerja, dan membantu peserta prestasi dalam kegiatannya, terutama mengenai pengertian dan ketrampilan. Pelatihan mempunyai beberapa ciri khas antara lain:

- Pada suatu pelatihan, praktek merupakan hal yang sangat dipentingkan.

- Pelatihan rnenitik beratkan pada ketrampilan, jadi lebih berat pada pengembanganpsikomotor

- Pada pelatihan diharapkan agar peserta dapat rneningkatkan ketrampilan rnelalui suatu proses belajar yang sempuma.

- Pelatihan diberikan didalam waktu kerja

- Pelatihan diberikan pada waktu yang relatif lebih pendek.

a. Tujuan Pelatihan

Menurut Cut lurnali (2004). bahwa tujuan pelatihan adalah agar para pegawai dapat menguasai pengetahuan. keahlian dan prilaku yang ditekankan dalam programprogram pelatihan dan untuk diterapkan dalam aktivitas sehari-hari para karyawan. Pelatihan juga rnempunyai pengaruh yang besarbagi pengembangan perusahaan.Simamora (2005:51) rnenyatakan tujuan-tujuan utama pelatihan adalah :

- Memutakhirkan keahlian pada karyawan sejalan dengan perubahan teknologi.Melalul pelatihan, pelatih (trainer) memastikan bahwa karyawandapat menggunakan teknologi baru secara efektif.

- Mengurangi waktu belajar bagi karyawan untuk rnenjadi kompeten dalam pekerjaan. Seorang karyawan harus rnemiliki keahlian dan kemampuan yangstandar kualitas yang diharapkan.

- Membantu memecahkan perrnasalahan operasional. Serangkaian pelatihan dalam berbagai bidang yang dibcrikan oleh perusahaan maupun konsultan luar yang membantu parakaryawan dalarnmemecahkan

masalahorganisasional dan melaksanakan pekerjaan secara efektif.

- Mempersiapkan pegawai untuk promosi. Pelatihan berguna bagi karyawanuntuk memperoleh keahlian-keahlianyangdibutuhkan untuk pekerjaan berikutnya dijenjang atas organisasi dan memudahkan transisi dari pekerjaan karyawan saat ini keposisi atau pekerjaan yang melibatkan tanggung jawab yang lebih besar.

- Mengorientasikan karyawan terhadap organisasi. Program orientasi dapat mengurangi kecemasan pegawai, menghemat waktu dan rekan kerja mengembangkan sikap positif terhadap perusahaan dan rnenciptakan pengharapan pekerjaan yang realistik. Kemudian tujuan latihan menurut Manullang (2004:79) yaitu :

1. Agar karyawan yang mengikuti diktat dapat melakukan pekerjaan kelak lebihefisien.

2. Latihan dapat rnengurangi pengawasan

3. Untuk mengstabilkan karyawan untuk mengurangi perputaran tenaga kerja(Labour Turn O..er)

b. Manfaat Pelatihan

CUI zurnali (2004) memaparkan beberapa mamfaat pelatihan yang diselenggarakan oleh perusahaan yang dikemukakan oleh Nne. llollenbcck. Gerhart, Wright (2003), .yaitu :

- Meningkatkan pengetahuan para karyawan atas budaya dan para pesaing luar.

- Membantu para karyawan yang mempunyai keahlian untuk bekerja dengan tekhnologi baru. 
- Membantu para karyawan untuk memahami bagaimana bekerja secara efektif dalam untuk menghasilkan rasa dan produk yang berkualitas.

- Memastikan bahwa budaya perusahaan menekankanpada inovasi, kreativitas dan pernbelajaran.

1. Perbedaan Pendidikan dan pelatihan Notoatrnodjo (2003) menyatakan bahwaperbedaan istilah Pendidikan dan Pelatihandalam suatu institusi secara teori dapat dikenal dari hal-hal berikut :

A. Manfaat dan Dampak Pendidikan dan pelatihan (Diklat)

Manfaat dan dampak yang diharapkan dari penyelenggaraan Diklat bagi karyawan/relawan suatu perusahaan/organisasi rneliputi :

1. Peningkatan keahlian kerja meningkatkan keahlian bekerja tidak kebiasaan secara rutin pada setiap waktu dalam suatu tugas atau pekerjaan juga merupakan sarana positif untuk meningkatkan keahlian tenaga kerja.

2. Pengurangan Keterlambatan Tenaga Kerja. Berbagai alasan seringkali muncul dari tenaga kerja atas tindakan yang mereka lakukan meskipun sering sekali alasan itu tidak masuk akal. misalnya keterlambatan kerja karena faktor tempat tinggal, gangguan lalu lintas di perjalanan dan sebagainya.

3. Mengurangi Timbulnya Kecelakaan KerjaKerusakan Alat/Bahan inventaris organisasi atau perusahaan sebagai penunjang aktivitas kerjaKecelakaan bekerja itu biasanya timbul:kerja kelalaian karyawan/relawan ataupun pihak perusahaan/organisasi. ketidaktahuan tenaga kerja tentang keselamatan kerja dan penggunaan peralatan didalam suatu pekerjaan.

4. Peningkaran ProduktifitasKerjaTujuan setiap perusahaan/organisasi adalah memperoleh tingkat produktifitas tinggi, setiapproses mengalami setiap peningkatan sesuai dengan yang diharapkan. Untuk memperoleh hal tersebut didukung beberapa faktor diantaranya adalah kondisikerja para tenaga kerja. Apabila tenaga kerja tidak memiliki gairah dan semangat bekerja. tentu produktifitas kerja pun akan merosot atau rendah, Sebaliknya, apabila tenaga kerja memiliki semangat dan gairah kerja tinggi keluaran (produkiifiatas kerja) akan tinggi pula.

5. Peningkatan Kecakapan kerjaPerkembangan teknologidan kornputerisasi yang makin maju, menuntut tenaga kerja harus mampu menggunakannya. Untuk itu, tenaga kerja dituntut mengembangkan kemampuan dan kecakapan kerjanya baik secara manual maupun teknologi.

6. Meningkatkan Rasa Tanggung jawab masing-masing tenaga kerja sebenarnya rnemiliki tanggung jawab,banyak tingkatan dan kebutuhannya berbedabeda bergantung pada beban tugas dan pekerjaan yang diserahkan padanya, tanggung jawab adaIah kewajiban seorang tenaga kerja untuk melakukan pekerjaan yang diserahkan kepadanya dengan sebaik- baiknya sesuai dengan kemampuan masing-masing. Makin tinggi hierarkiperusahaan/organisasi makin besar tanggungjawab yang diserahkan kepadanya.

B. Metode serta Teknik Pendidikan dan Pelatihan

Menurut DR. D. Siswanto Sastro Hadiwiryo 12005. hal :214) dan Prof.Dk.Soekidio Noroadmojo (2005) .haJ :59-69), metode serta teknik pendidikan dan pelatihan juga dapat dilakukan dengan berbagai cara diantaranya :

1. Pelatihan di tempat tenaga kerja

Pelatihan di tempat tenaga kerja yang dimaksudkan untuk memberikan petunjuk khusus kepada paratenaga kerja gunamelakukan tugas serta pekerjaannya. Pelatihan di tempat kerja penyelenggaraanya pada tempat kerja berupa pelatihan praktek dengan menggunakan situasi pekerjaan sebagai sarana untuk memberi instruksi /petunjuk. Jenis metode ini sering dijumpai karena dianggap sebagai metode yang efektif dan efisien serta alokasi biaya juga murah.

2. Kuliah

Dalam pelaksanaanya, rnetode ini banyak sisi positifnya yaitu selain dapat menampung peserta dalam jumlah banyak juga dapat menggunakan media cetak, elcktronik, misalnya hagan. chart, kaset, video, film 
maupun jenis peraga lainnya. Namundisisi lain, metode ini seringkali dipandang kurang efektif karena biasaayakurang rnemberikan pcngembangan diantara peserta dan lebih banyak bersifat memberi (given) yairu hanya memindahkan ide, pengetahuan, keahlian dan kecakapan dari para pengajar kepada para peserta pendidikan dan pelatihan.

3. Studi Kasus

Penyajian laporan kasus suatu kejadian yang telah diteliti, di analisis tetapi masih memerlukan keputusan peserta secara pemecahannya, Fungsinya untuk menganalisis masalah dalam mendemontrasikan ringkasan suatu kasus secara jelas danpadat.

4. Permainan Peranan (Role Playing)

Metode role playing dapat didefenisikan sebagai suatu metode pendidikan dan pelatihan dimana terlibat persis interaksi hubungan individu baik sebenarnya maupun keliruyang diperankan secara spontan. Peragaan ini biasanya disusun oleh suatudiskusi dan analisis unruk menentukan hal-hal yang telah terjadi, mengapa terjadi.bagaimana masalah tersebut mendapatkan sebuah solusi.

5. Seminar dan lokakarya

Seminar adalah suatu studi kasus yang biasanya diikuti Iebih daripada 30 orang dan dipimpin oleh seorang yang ahli didalam bidang dipelajarinnya, Sedangkan lokakarya adalah penemuan dari orang-orang yang bcrpengalaman dan ahli-ahli yang dapat mernbantu, guna membicarakan masalah atau pelajaran yang dirasakan sulit untukdipecahkan sendiri.

6. Simposium Simposium adalah serangkai pembicaraan yang diberikan oleh beberapa ahli dalam bidangnya rnasing-masing dengan topik yang berlainan tetapi berhubungan erat satu sama lainnnya,

Dari uraian diatas dapat disimpulkan bahwa pelaksanaan pendidikan dan pelatihan bagi setiap pegawai ncgeri sipil sangat membantupelaksanaan tugas-tugas pegawai, sehinggapegawai yang bersangkutan lebih profesional dan terampil daJam menjalankan tugas yang diembannya.

\section{HASIL PENELITIAN DAN PEMBAHASAN}

Mengenai pembentukan Kecamatan atau kota semuanya telahdi atur dalam Undang - undang Dasar 1945. bukan berdiri dengan sendirinya tetapi sudah ada ketentuan dalam Undang-Undang tentang pembentukan Provinsi. Kabupaten atau Daerah.

Kantor Camat adalah salah satu sarana untuk memberikan pelayanan bagi masyarakat dalam hal yang rnenyangkut dengan kependudukan. Untuk menyelenggarakan tugas yang dimaksud Kantor Camat rnemberikan pelayanan jasa berupa:

1. Pelayanan Pembayaran Pajak Bumi,

2. Pelayanan pengambilan surat tentang penduduk yang diperlukan. oleh masyarakat

3. Memberikan data tentang kependudukan di daerah Kecamatan dan masih banyak hal-hal lain yang diberikan oleh kantor camat tersebut.

A. Struktur organisasi kantor camat

Sebagaimana yang telah dikemukakan sebelumnya bahwa pembentukan struktur organisasi kantor camat berdasarkan pada Qanun Kabupaten Pidie nomor 6 tahun 2008 tentang susunan organisasi dan tata kerja pemerintahan kecamatan dalam kabupaten pidie.

Dalam suatu organisasi segala aktivitasnya, terdapat hubungan antara orangorang yang menjalankan aktivitas tersebut. Makin banyak kegiatan yang dilakukan dalam suatu organisasi, makin komplek pula kegiatan hubungan-hubungan yang ada. Untuk itu diperlukan suatu struktur yang menggambarkan tentang hubungan-hubungan tersebut termasuk antara masing-masing kegiatan atau fungsi. Penetapan suatu struktur organisasi yang tepat merupakan suatu lembaga/instansi pemerintah.

Dengan menitik beratkan pada qanun tersebut. Maka ditetapkan struktur organisasi kantor camat di tiap-tiap kecamatan dalam kabupaten pidie provinsi aceh yang meliputi :

1. Camat

2. Sekretaris

3. Seksi tata pemerintahan

4. Seksi pemberdayaan dan ketertiban umum

5. Seksi kesejahteraan sosial dan keluarga 
6. Seksi keistimewaan aceh

7. Kelompok jabatan fungsional

B. Pendidikan dan Pelatihan Pegawai

Dalam rangka meningkatkan karir pegawai, maka pimpinan kantor Kecamatan telah berupaya agar pegawai yang ada dalam lingkungannya dapat mengikuti berbagai program pendidikan dan pelatihan, baik yang dilakukan didalam maupun diluar negeri dengan tidak mengabaikan syarat-syarat dan ketentuan yang ada.

Memberikan kesempatan kepada para pegawai untuk mengikuti pendidikan dan pelatihan merupakan suatu pembinaan untuk meningkatkan kemampuan dan keterampilan pegawai untuk meningkatkan daya guna dan hasil guna dari pelaksanaan tugas pegawai yang bersangkutan.

Sebagaimana yang telah dikemukakan sebelumnya penyelenggaraan pendidikan dan pelatihan pegawai negeri sipil pada kantor camat meliputi beberapa hal antara lain. Formasi. Pengadaan pegawai negeri sipil pendidikan dan pelatihan serta daftar urut kepangkatan.

Hasil penelitian dari unsur-unsur tersebut diatas, dapat diuraikan satu persatu dibawah ini :

\section{Formasi}

Dalam rangka usaha penyelenggaraan pemerintah dan pembangunan secara berdaya guna dan berbasil guna dan berkelanjuran, maka perlu ditetapkan penyusunan formasi bagi Satuan Organisasi Pemerintah. Sesuai ketentuan pasal 7 Undang-undang Nomor 43 Tahun 1999 tentang perubahan atas Undangundang Nomor 8 Tahun1974) tentang Pokokpokok Kepegawaian). Pegawai negeri sipil diangkat dalam jabatan dan pangkat tertentu, dengan demikian pengertian formasi termasuk didalamnya jurnlah susunan jabatan

pegawai negeri sipil yang diperlukan satuan organisasi pemerintahan untuk mampu melaksanakan tugas pokok dalam jangka waktu tertentu.

2. Pengadaan Pegawai Negeri

Melalui surat keputusan pengangkatan, maka setiap pegawai negeri sipil mempunyai kekuatan hukum untuk berfungsi dan mempunyai hak dan kewajiban sebagai seorang pegawai negeri. Pengadaan atau pengangkatan pegawai didasarkan kcpada kebutuhan pegawai berdasarkan volume kerja.

Memberikan kesempatan kepada pegawai negeri sipil untuk mengikuti pendidikan dan pelatihan merupakan suatu pembinaan untuk meningkatkan kemampuan dan ketrampilan pegawai dalam melaksanakan tugasnya, Sekaligus dapat meningkatkan kualitas untuk meningkatkan daya guna dan hasil guna dan Pelaksanaantugas pegawai yang bersangkutan. Dan kenyataan yang diperoleh, rnaka dapatdisimpulkan hanya 40 persen atau 70 persen yang sudah mengikuti pendidikan dan pelatihan, sedangkan yang lain masib belum pernah mengikuti berbagai pendidikan dan pelatihan.

\section{Daftar Urut Kepangkatan ( DUK )}

Membuat daftar pegawai menurut urutan pangkat mulai dari yang tertinggi sampai dengan yang terendah rnerupakan salah satu unsur yang harus di laksanakan dalam Penyelenggaraan Pendidikan dan Pelatihan terhadap Pegawai pada Kantor camat.

Pembuatan Daftar urut Kepangkatan didasarkan pada Peraturan Perundangundangan yang berlaku.Sesuai dengan kenyataan yang ditcmui dan hasil penelitian menunjukkanbahwa kantor Camatyang ada di Kabupaten Pidie telah membuat Daftar urut kepangkatan pegawai dimulai dari pegawai yang berpangkat paling tinggi yaitu golongan IV/a sampai dengan pegawai paling rendah yaitu golongan $\mathrm{I} / \mathrm{b}$.

Berdasarkan kenyataan tersebut diatas dapat dikatakan babwa pembuatan Daftar Urut Kepangkatan pegawai pada kantor Camat di Kabupaten Pidie telah terlaksana sebagaimana mestinya, semua data tentang pegawai telah dimuatdi dalamnnya.

Kantor Camat adaIah sebagai salah satu fungsi negara dan sarana untuk memberikan pelayanan bagi masyarakat dalam hal yang menyangkut dengan kependudukan, Dan memberikan pelayanan jasa yaitu berupa Pelayanan Pembayaran Pajak Bumi, Pelayanan Pengambilan Surat tentang penduduk yang diperlukan oleh masyarakat, memberikan data tentang kependudukan dan masih banyak hal-hal lain yang diberikan oleh Kantor Camat.

Untuk kelancaran penyelenggaraan tugas Pemerintah dan Pembangunan. Nasional sangat tergantung pada kesempurnaan Aparatur Negara Hukum khususnya Pegawai Negeri Sipil. Karena itu dalam rangka mencapai tujuan nasional yakni mewujudkan masyarakat madani yang taathukum. berperadaban modem. demokratis, makmur, adil dan bermoral tinggi. serta diperlukan pegawai 
negeri yang rnerupakan unsur aparatur negara yang bertugas sebagai abdi masyarakatyang harus menyelenggarakan pelayanan secara adil dan merata kepada masyarakat dengan dilandasi kesetiaan dan ketaatan kepada Pancasila dan Undang-undang Dasar 1945. untuk kelancaran dan perkembangan produktivitas kerja pegawai diperlukanadanya pengembangan kemampuan melalui Pendidikan dan Pelatihan dengan adanya pengembangan pengetahuan dan kemampuan kerja maka akan menjadikan pegawai lebih dan kreatif dan juga akan berkontribusi dengan baik dalarn semua pekerjaan yang diberikan.

Bahwa masing-masing pegawai negeri sipil pada kantor Camat menduduki jabatan sesuai dengan pangkat, begitu juga halnya penernpatan para pegawai disetiap seksi, dapat disimpulkan sudah memenuhi standart kepangkatan. Pengalaman kerja dan pendidikan, berdasarkan Undang-undang Nomor: 43 Tahun 1999 tentang Perubahan atas Undang-undang Nomor 8 Tahun 1974 tentang Pokok-pokok Kepegawaian.

Begitu juga halnya menyangkut dengan keadaan kedudukan pegawai negeri sipil dikantor camat menurut hasil peneltian sudah sesuai karena tidak ditemukan adanya pegawai yang lebih rendah pangkatnya membawahi pegawai yang pangkatya yang lebih tinggi. Sesuai dengan Peraturan Pemerintah Republik Indonesia Nomor 99Tahun 2000 tentang Kenaikan Pangkat Pegawai Negcri Sipil, bab 11 Pasal 33 yaitu. pegawai negeri sipil yang berpangkat lebih rendah tidak boleh membawahi pegawai negeri sipil yang berpangkat lebih tinggi, kecuali membawahi pegawai negeri sipil yang menduduki jabatan fungisional tertentu. Begitu juga dalam hal pengangkatan dalam jabatan terhadap para pegawai menurut hasil penelitian pada kantor Camat di Kabupaten Pidie, sudah tepat, karena berdasarkan Pedoman Aturan Kepegawaian yaitu Undangundang Nomor 43 tahun 1999 dengan Perubahan atas Undang-undang Nomor 8 Tahun 1974 tentang Pokok-pokok Kepegawaian Pasal 17ayat (2)"' Pengangkatan Pegawai Negeri Sipil dalam suatu jabatan dilaksanakan berdasarkan Prinsip Profesionalisme sesuai dengan Kompetensi. Prestasi kerja dan jenjangpangkat yang ditetapkan untuk jabatan itu sertasyarat obyektif lainnya tanpa membedakanjenis kelamin, suku, agama. ras atau golongan ",

1. Keadaan umum pegawai

Pegawai merupakan bagian yang tidak dapat dipisahkan dalam usaha pencapaian tujuan organisasi, pegawai merupakan tulang punggung dalam organisasi, baik organisasipemerintah rnaupun organisasi swasta. Sesuai dengan kenyataan yang diperoleh dari daftar urut kepangkatan pada kantor camat kabupaten pidie.

Pengangkatan pegawai pada salah saTru instansi, baik instansi pemerintah maupun non pemerintah tidak harus rnemperhatikan jenis kelamin, karena hal itu bukan merupakan salah satu syarat mutlak, asalkan sudah memenuhi syarat untuk diterima sebagai pegawai. maka ia dapat bekerja sesuai dengan kemampuannya, meningkatkan produktivitas kerja sesuai dengan perkembangan dan kemajuan zaman yang modem, maka di anjurkan bagi setiap pegawai negeri sipil, agar mampu bekerja dengan menggunakan perangkat tekhnologi seperti perangkat elektronik komputer. untuk rnenunjang kesempurnaan tugas-tugas dengan baik dan tepat waktu.

Setiap pegawai Kantor Camat Kabupaten Pidie dari kenyataan tersebut maka ditemukan ada 37.5\%yang mampu mengaplikasikan komputer dengan baik, $(41,7 \%)$ kurang mampu, dan $(20,8 \%)$ tidak mampu menggunakan aplikasi komputer.

Maka dari hasil penelitian tersebut dapat simpulkan bahwa tidak seluruhnya pegawai negeri sipil dikantor Camat Kabupaten Pidie mampu menggunakan aplikasi komputer sebagai salah satu penunjang dalam pekerjaan perkantoran.

Pengaruh pendidikan dan pelatihan terhadap produktivitas kerja pegawai kantor Camatdi Kabupaten Pidie sebagaimana yang telah dikemukakan dalam bab sebelumnya menyangkut beberapa aspek yang dikaji dalam penelitian ini, aspek-aspek tersebut meliputi :

\section{Formasi}

Dari kenyataan yang diperoleh dari hasil penelitian dapat dikatakan bahwaditetapkan sesuai dengan kebutuhan, dan semua formasi yang telah tersedia setelah diisi menurut bidangnya masing-masing, sehingga tidak ada lagi formasi yang kosong.

Dari kenyataan tersebut, rnaka dapat diambil suatu kesimpulan bahwa kantor Camat di Kabupaten Pidie tidak ada lagi 
formasi pegawai yang kosong, karena sesuai formasi yang ada telah di isi sesuai dengan kebutuhannya,

2. Daftar urut kepangkatan (OUK) Menyusun daftar kepegawaian menurut urutan tingkat pangkat mulai dari yang tertinggi sampai dengan yang terendah adalah salah satu unsur yang harusdilaksanakan dalam penyelenggaraan pendidikan dan pelatihan. Dengan adanya daftar urut kepangkatan pegawai tersebut. maka inventarisasi pegawai dapat mencerminkan keadaan pegawai pada suatu instansi yang jelas dengan segala identitasnya, Daftar urut kepangkatan tersebut dapat dijadikan pedoman terhadap skala prioritas dalam pemamfaatan sumber daya manusia yang terutama adalah didasarkan kepada tingkar pangkar yang dimiliki.

\section{PENUTUP}

Berdasarkan pada uraian-uraian yang telah disampaikan pada bab-bab sebelumnya terhadap permasalahan yang diteliti. Maka didalam bab penurup akan diambil beberapa kesimpulan dan saran-saran yairu:

A. Kesimpulan

1. Pengaruh pendidikan dan pelatihan terhadap produktivitas kerja pegawai Kantor camat di Kabupaten Pidiebelum terlaksana sebagaimana yang diharapkan, karena masih ditemui beberapa faktor yang menjadi hambatan.

2. Masih rendahnya prestasi dan disiplin kerja pegawai,kurangnya pemahaman pegawai terhadap tugas,fungsi dan wewenang, yang seharusnya bisa rnenjadi pemahaman dan pengembangan pengetahuan pegawai terhadap pekerjaan,

3. Dalam mencapai produktivitas kerja yang baik pengetahuan danketrampilan amat sangat dibutuhkan dalam menunjang kemajuan dalam pekerjaan. Pendidikan dan pelatihan merupakan sarana yang sangat tepat unrukmenciptakan kepribadiankepribadian pegawai agar lebih terbuka untuk menjadi lebih aktif dan kreatif

4. Pengembangan karakter diri dan pengembangan pengetahuan sangatlah wajib dilakukan, karena seiring perkembangan jaman yang sangat serba canggih dan instan, seorang pegawai harusmampu berjalan searah dengan kemajuan tersebut agar tidak terlalu ketinggalan dan monoton dalam bekerja. Kepribadian seorang pegawaijuga sangat penting ditanamkankediplinan, tanggung jawab yang tinggi, ketaatan, dan kesetiaan terhadap pekerjaan sangatlah mendukung untuk kemajuan dan keberhasilan seorang pegawai terhadap produktivitas kerja kantor.

B. Saran-saran

1. Kepada seluruh pegawai kantor camat yang ada di wilayah Kabupaten Pidie disarankan untuk mengikuti program pendidikan dan pelatihan, agar seluruh pegawai menjadi lebih berkembang baikdan segi pengetahuan, dan ketrampilan, Sehingga pegawai kantor camat di Kabupaten Pidie menjadi Iebih aktif, kreatif dan terampil.

2. Kepada pimpinan kantor camat di wilayah Kabupaten Pidie, hendaknya lebih aktif lagi dalam menangani pegawai, khususnya bagi pegawai yang kurang disiplin, dan juga memberikan petujuk pelaksanaan tugas dan peningkatan intensitas pengawasan.

3. Hendaknya pimpinan kantor camat di kabupaten pidie disarankan untuk mengusahakan agar seluruh pegawai yang telah memenuhi persyaratan agar berkesempatan mengikuti berbagai program pendidikan dan pelatihan yang diselenggarakan.

4. Disarankan kepada pimpinan pusat dan daerah, agar dalam menjalankan program pendidikan dan pelatihan terjadwal secara baik dan tidak mengganggu rutinitas pekcrjaan.

\section{DAFTAR PUSTAKA}

Cut nurnali, 2004, pengaruh pelatihan dan motivasi terhadap prilaku produktif karyawan pada divisi long distance PT Telkom Indoneisa, Tbk, Tesis, Program Pasca Sarjana Unpad, bandung

Dessler, gary (2007), Organisasi dan motivasi Jakarta : bumi aksara 
Hasibuan, melayu, S.P. 2006, manajemen sumber daya manusia, cetakan kelima Edisi Revisi, Jakarta : Penerbit Bumi Akasara

Hasbullah, dasar ilmu pendidikan 2005, Jakarta penerbit : PT Raja Grasindo Persada

Hasibuan Melayu, SP, (2002) motivasi yang sukes dalam sepekan Jakarta : PT Kosaint blanc indah corp.

Manullang, M. (2004) Latihan dan pengembangan pegawai penerbit alumni bandung

Nainggolan, H, Pembinaan pegawai negeri sipil, pertja (BKn), Jakarta

Notoatmodjo, (2003) prilaku keorganisasian, edisi kesepuluh PT. Indonesia Kelompok Gramedia
Simamora, (2005) prilaku organisasi : konsep kontraversi, aplikasi Jakarta : PT Prihallindo

Umar, Husein, (2000) metode penelitian dan aplikasi, BPFE Yogjakarta

Sinungan, mucghdarsyah, 2003. Produktivitas apa dan bagaimana, bumi aksara Jakarta

Undang-undang Nomor 2 tahun 1989 tentang pendidikan

Undang-undang republic Indonesia no. 11 Tahun 2006 tentang pokok-pokok kepegawaian

Peraturan pemerintah Republik Indonesia No. 01 tahun 2000 tentang pendidikan dan pelatihan jabatan pegawai negeri sipil 